\title{
Degradation of myosin heavy chain and its potential as a source of natural bioactive peptides in dry-cured ham
}

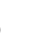

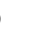

10

11

Corresponding author address: Leticia Mora (lemoso@iata.csic.es) Tel: +34963900022 ext. 2114; Fax: +34963636301

$$
\text { Mora, L.*, Gallego, M. and Toldrá, F. }
$$

Instituto de Agroquímica y Tecnología de Alimentos (CSIC), Avenue Catedrático Agustín Escardino, 7, 46980, Paterna (Valencia), Spain 


\section{Abstract}

32 Myofibrillar proteins are extensively degraded by muscle endo- and exopeptidases during

33 the ageing of meat and the processing of meat products. One of the most studied products

34 is dry-cured ham. This degradation implies changes in the product in terms of texture

35 (mainly due to calpains and cathepsins endopeptidases) and flavour (due to the action of

36

37 exopeptidases) and defines its final quality. During the last decade, naturally generated peptides from the myofibrillar proteins titin, myosin light chain, troponin T, LIM domainbinding protein 3 , and actin have been identified using peptidomic approaches, showing also the potential to act as bioactives in the human body when ingested. In this study, a mass spectrometry in tandem approach has been used for the identification of peptides naturally generated during the proteolysis of myosin heavy chain protein occurred after 9 months of Spanish dry-cured ham processing. The potential of these peptides to act as bioactives has also been studied.

Keywords: mass spectrometry in tandem, peptidomics, dry-cured meat, proteolysis, bioactives, myofibrillar proteins.

.


56 The processing of dry-cured meat products includes drying and ripening steps that result

57 in the progressive reduction of water activity and the occurrence of proteolysis. This

58 biochemical reaction implies the degradation of proteins by the action of endogenous peptidases and the generation of oligopeptides, small peptides, and free amino acids. Main enzymes of meat products involved in this process are endogenous muscle peptidases in loin and dry-cured ham, and the combined effect of muscle and microbial enzymes in products such as semidry- and dry-fermented sausages (Toldrá and Reig, 2015). The degradation of muscle proteins starts with the action of the muscle endopeptidases cathepsins and calpains and the generation of a large amount of polypeptides (Toldrá, 2002), and continues with the action of certain groups of muscle exopeptidases that are able to degrade protein fragments into small peptides such as di-

67 and tripeptides, and free amino acids (Toldrá and Flores, 1998; Toldrá, 2006).

68 Myosins are a basic and majoritarian component of skeletal muscles that participate together with actin, tropomyosin, and troponin proteins in muscle contraction as well as in a wide variety of non-muscular cell movements. A myosin molecule is a hexamer consisting of two heavy chains (MHC) and two light chains (MLC) (Goll et al., 2008).

72 The intense proteolysis suffered by structural muscle proteins in general, and particularly by MHC, during the dry-curing process of ham has been extensively described. For that, methodologies such as electrophoresis on polyacrylamide gels (SDS-PAGE) to separate the proteins, and matrix-assisted laser desorption/ionisation (MALDI) mass spectrometry

76 for the identification of proteins by peptide mass fingerprint have been used (Di Luccia 77 et al., 2005; Fabbro et al., 2016). However, the use of mass spectrometry in tandem 78 (MS/MS) is crucial to elucidate the sequence of the small peptides naturally generated during the processing. 
Bioactive peptides are inactive when they are part of parent protein, but turn active when released due to the action of enzymes. In this respect, pork raw meat has been previously identified as a source of ACE-inhibitory peptides when digested under controlled conditions of hydrolysis as well as after in vitro gastrointestinal (GI) digestion (Arihara et al., 2001; Katayama et al., 2003; Escudero et al., 2010; Escudero et al., 2012). In a similar way, aged beef loin has been described to contain ACE-inhibitory and antioxidant peptides which remain active after cooking and simulated GI digestion (Mora et al., 2017). Finally, the generation of bioactive peptides such as ACE-inhibitory and antioxidant peptides from dry-cured meat products has also been in the focus of attention during the last years due to the importance of meat proteome as a source of functional biopeptides naturally generated during the ripening processes (Mora et al., 2016). In this study, the identification of peptide sequences naturally hydrolysed from MHC in the fast-glycolytic Biceps femoris muscle during the processing of 9 months Spanish drycured ham has been achieved using mass spectrometry in tandem. The potential of bioactive peptides generation has also been discussed.

\section{Material and methods}

\subsection{Chemicals and reagents}

Trifluoroacetic acid (TFA) was purchased from Sigma Aldrich (St. Louis MO, USA), whereas the other reagents used in mass spectrometry analysis such as acetonitrile (ACN),

100 formic acid (FA), and water were of MS grade and purchased from Scharlab (Barcelona, 101 Spain). Reagents used in the peptide extraction were of analytical grade and purchased 102 from Scharlab (Barcelona, Spain).

\subsection{Extraction and fractionation of peptides using size-exclusion chromatography}


104 A total of six dry-cured hams from pigs of industrial genotypes Landrace $\mathrm{x}$ Large White were processed until 9 months of curing in a local factory in Spain. Then, the extramuscular fat of Biceps femoris muscle was removed and the dry-cured muscle was

107 processed according to Mora et al. (2011a). The extracted peptides were fractionated 108 depending on their molecular weight using a Sephadex column (G25 stationary phase, $1092.5 \times 65 \mathrm{~cm}$ from Amersham Biosciences, Uppsala, Sweden) by size-exclusion 110 chromatography according to Mora et al. (2011a). The fractions corresponding to the molecular weight peptides within the range 1000-3000 Da were pooled together and lyophilised. The mix was suspended in $5 \mathrm{ml}$ of $0.1 \% \mathrm{TFA} / \mathrm{ACN}(95: 5, \mathrm{v} / \mathrm{v})$ for further analysis.

2.3. Reversed-phase high-performance liquid chromatography (RP-HPLC) of the selected peptide fractions

The RP-HPLC methodology was that described in Mora et al. (2011a). Briefly, a total of $100 \mu \mathrm{l}$ of the isolated peptides was injected in a Symmetry column with C18 stationary 118 phase $(250 \times 4.6 \mathrm{~mm}, 5 \mu \mathrm{m})$ from Waters (Milford, MA), and using an HPLC Agilent 1191100 series system (Agilent Technologies, Palo Alto, CA). Mobile phases were solvent A, $0.1 \%$ TFA, and solvent B, $0.05 \%$ TFA/ACN (5:95, v/v). The chromatographic separation was 5 min with solvent $\mathrm{A}$ in isocratic gradient, and 70 min with a linear gradient from 0 to $40 \%$ of solvent $\mathrm{B}$. The separation was done using a flow rate of 1 $\mathrm{ml} / \mathrm{min}$ and at $25^{\circ} \mathrm{C}$ of column temperature, and monitored at $214 \mathrm{~nm}$ to detect the

124 peptides. Finally, fractions of $1 \mathrm{ml}$ were collected with an automatic collector connected to the HPLC waste tube and lyophilised for its later identification by MS/MS.

\subsection{Acquisition of mass spectrometry data and database search}

127 Peptides previously obtained in RP-HPLC were analysed by MS/MS using a liquid 128 chromatography system Ultimate Plus/Famos nano LC system (LC Packings, 
Amsterdam, The Netherlands) and the QSTAR XL hybrid quadrupole-Time-of-Flight mass spectrometer (ABSCIEX, CA, USA) with a nano-electrospray ion source.

131 Fractions of $1 \mathrm{ml}$ collected from the RP-HPLC separation and previously lyophilised were 132 dissolved in $60 \mu \mathrm{l}$ of loading buffer $(0.1 \%$ of FA and $2 \%$ of ACN $)$ and injected. Samples were cleaned and concentrated on a C18 PepMap trap column $(0.3 \times 5 \mathrm{~mm}, 3 \mu \mathrm{m}$; LC

134 Packings, Dionex Company, Amsterdam, The Netherlands) at a flow rate of $40 \mu \mathrm{l} / \mathrm{min}$ 135 with $0.1 \%$ of TFA as mobile phase. After three minutes, the trap column was switched 136 in-line with a Dionex C18 PepMap column from LC Packings $(0.075$ x 150 mm, $3 \mu \mathrm{m}$;

137 Dionex Company, Amsterdam, The Netherlands). Mobile phases were solvent A, with $1380.1 \%$ FA and solvent B, with $0.1 \%$ FA in $95 \%$ ACN. The LC separation of the peptides was done during 30 minutes in a linear gradient from $95 \%$ to $50 \%$ of solvent $\mathrm{A}$ at a flow rate of $0.2 \mu \mathrm{l} / \mathrm{min}$. The column outlet was directly coupled to a nano-electrospray ion source. QSTAR instrument was used in positive mode. TOF MS survey scan was

142 registered for mass range $m / z 350$ to 1800 followed by MS/MS scans of the three most

143 intense peaks. Source parameters and spray were optimised using a protein mixture 144 digestion with trypsin (LC Packings; P/N 161088; Dionex Company, Amsterdam, The 145 Netherlands).

146 Database search was done using Mascot 2.6 in combination with Mascot Daemon 147 interface 2.5 (Matrix Science, Inc., Massachusetts, USA) 148 (hppt://www.matrixscience.com), and the ProteinPilot ${ }^{\mathrm{TM}}$ software (ABSCIEX, CA, 149 USA). NCBInr protein database was used to identify the peptides. Main parameters 150 considered were unknown enzyme and Sus scrofa taxonomy. BLAST 151 (https://blast.ncbi.nlm.nih.gov/Blast.cgi) was used in the alignment of the different 152 isoforms of MHC sequences. 


\section{Results and discussion}

155 During the last decade, MS/MS has been the method of choice for the identification of 156 the naturally generated peptides during meat processing (maturation, fermentation, dry157 curing, ...) and different studies in this respect have been published. The total number of 158 identified peptides from different myofibrillar and sarcoplasmic proteins in dry-cured 159 ham samples is compiled in Table 1. This table also includes the potential sequences of $160 \mathrm{di}$ - and tripeptides that could have been generated from the action of muscle exopeptidases on the identified peptides. The mass spectrometric approach used in these studies is optimal for the identification of peptides from 800 to $3000 \mathrm{Da}$ that are the most common sizes after natural proteolytic processes.

164 Despite the importance of MHC as responsible, together with MLC, for contractile 165 properties in muscle, the identification of naturally generated fragments from MHC has been scarcely reported to date. In fact, several sequences of MYH1_PIG, MYH4_PIG and MYH7_PIG were previously described in Iberian dry-cured ham with 24 months of curing (Mora et al., 2015b), as well as a total of 11 and 7 oxidised peptides from MYH1_PIG and MYH7_PIG, respectively, were identified by nESI-LC-MS/MS in PDO

170 Teruel dry-cured ham of 14 months of curing (Gallego et al., 2015b).

171 In mammalian skeletal muscles there are four MHC isoforms, the three fast $(2 \mathrm{a}, 2 \mathrm{x}$, and 2b) isoforms and the slow (1) isoform, that correspond to UniProt database entry names MYH1, MYH2, MYH4, and MYH7, respectively. Regarding pig muscle proteome, they

174 share most of their proteomic sequence as shown in Figure 1 of Supplementary

175 material. In this regard, Table $2 \mathbf{A}$ shows the identity percentage resulting from the comparison of the different sequences in BLAST database. These results show the high

177 percentage of homology between isoforms that comprises from $96.5 \%$ to $94.2 \%$ between MYH1, MYH2, and MYH4. In Table 2B, the different nomenclatures used by UniProt 
and NCBInr databases for same proteins are clarified. Regarding similarities between

180

181

182

183

184

185

186

187 sequences, MYH7_PIG presents the lowest homology with the other isomers as shown in Table 2A (between 81.7 and 81.8\%), but presents 100\% homology with Q29107_PIG protein, which is the partial sequence of slow myosin heavy chain-beta protein in UniProt database, as well as with the NCBInr protein described as myosin heavy chain slow isoform protein (gi|125987844).

In this study, peptides generated from Biceps femoris muscle in 9 months Spanish drycured ham have been extracted, isolated, and analysed by MS/MS, identifying a total of 51 peptides originated from the different isoforms of MHC. The fragments identified from MHC protein isoforms come from different sections of the sequences as it is shown in grey shadow in Figure 1 of Supplementary material, whereas Table 3 shows the sequences identified by nLC-MS/MS from 9 month Spanish dry-cured ham. Twentythree of the identified peptides share homology with MYH1_PIG, twenty-seven peptides with MYH2_PIG, and forty-five peptides with MYH4_PIG, whereas only five peptides were identified from MYH7_PIG. The knowledge of the generated MHC sequences contributes to elucidate the main enzymes acting during the curing period and proves the intense hydrolysis occurred. In this sense, Table 3 shows the action of endopeptidases enzymes in the scission observed between the peptides SSDQEMAIFGEAAPYLR (position 2-18) and KSEKERIEAQNKPFDAKTS (position 19-37), in both MYH1 and MYH4 proteins. The action of endopeptidases at this stage of curing makes sense because cathepsins $\mathrm{B}, \mathrm{H}$, and $\mathrm{L}$ have been previously reported to be stable even after 15 months of dry-cured ham processing (Toldrá et al., 1993; Toldrá, 1998), and cathepsin D activity remains up to 6 to10 months of processing (Rico et al.,1991). The optimal $\mathrm{pH}$ for cathepsins B and $\mathrm{L}$ is around 6, whereas for cathepsin $\mathrm{H}$ is 6.8. Cathepsin D shows an optimal $\mathrm{pH}$ range between 3.0 and 5.0. Finally, calpains are also able to participate in the 
degradation of proteins but only during the first weeks of the curing processing because of their low stability and optimal neutral pH of 7.5 (Toldrá and Flores, 1998). Different studies have described the relation of cathepsins with the disappearance of myosin protein. As an example, Hirao et al. (1984) incubated in vitro myosin from rabbit muscle with cathepsin B and proved the hydrolysis of MHC and MLC 2. Also the progressive disappearance of myofibrillar proteins like MHC, MLC 1 and MLC 2, and troponins C and I, as well as the generation of fragments with sizes between $50-100$ and 20-45 kDa have been reported by Toldrá et al. (1993).

According to the observed sequences derived from this study, there is also a contribution of exopeptidases to the generation of di- and tripeptides such as the dipeptides TS, TL,

214 FD, VK, AT and QT, and the tripeptides SRE, TVQ, NAS, KIE and GKM (Sentandreu et al., 2003). However, the action and stability of dipeptidyl peptidases depends on different factors such as the presence of salt or other peptides so it is difficult to determine their participation (Gianelli et al., 2000; Sentandreu and Toldrá, 2001). More specifically, the action of aminopeptidases and carboxypeptidases and their contribution to increase the free amino acids content in the muscle has been reported to last more than 12 months of processing and it is also proved with the release of $\mathrm{G}, \mathrm{K}, \mathrm{D}, \mathrm{T}, \mathrm{A}, \mathrm{L}, \mathrm{S}, \mathrm{I}$, and $\mathrm{F}$ free amino acids (Toldrá et al., 2000).

222 The composition in MLC and MHC of muscle fibres can determine the functional properties of muscles. In this respect, slow type fibres such as beta myosin heavy chain (MYH7_PIG) are rich in slow oxidative type muscles, whereas fast type fibres such as myosin heavy chain 2b (MYH4_PIG) are rich in fast glycolytic type muscles (Schiaffino and Reggiani, 1996). Biceps femoris muscle has been classified as a glycolytic muscle by different authors (Flores et al., 1996; Leseigneur-Meynier and Gandemer, 1991). This fact could explain the high amount of peptides derived from MHY4_PIG that have been 
identified in this study in comparison with peptides derived from MHY7_PIG. The relation of MHC fibres to meat quality parameters such as $\mathrm{pH}$, drip loss, colour, or yield force in pork meat has been well documented considering that muscles with fast glycolytic fibres (MHC 2x, 2b) are associated to better quality attributes than those muscles rich in slow-oxidative fibres (Chang et al., 2003). Also the influence of MHC

234 isoforms on fatty acids composition and sensory quality (juiciness, off-flavour, and tenderness attributes) has been proved (Kang et al., 2011). In relation to this, the type of fibres has been described to influence the early postmortem glycolytic rate and thus, the content in the different MHC isoforms may constitute a useful parameter for examining the variations of pork quality in PSE (pale, soft and exudative) muscles (Choi et al., 2007) as well as to differentiate between meat containing halothane gen (HAL)-negative and halothane carrier (Nn) pigs (Eggert et al., 2002).

241 On the other hand, certain food processes such as curing or fermentation in cheese, wine,

242 or meats have been described as good sources of bioactive peptides (Corrêa et al., 2014;

243 Mohanty et al., 2016), which are generally short sequences of 2-20 amino acids in length with molecular mass of approximately 400-3000 Da (Korhonen and Pihlanto, 2003). In this study, the identified peptides show a molecular mass distribution from 1000 to 2500

246 Da (Table 3). As it has been previously described, the presence of several di- and 247 tripeptides can be elucidated from the identified sequences showed in Table 3. In this respect, BIOPEP database (http://www.uwm.edu.pl/biochemia/index.php/ en/biopep) was used to identify potential bioactive peptides generated from the MHC protein. The dipeptides TS, TL, AT, VK, QT have been described as DPP IV inhibitors (Lan et al., 251 2015), whereas the dipeptide VK, obtained from soya source, was identified as ACE 252 inhibitor showing an $\mathrm{IC}_{50}$ value of $13 \mu \mathrm{M}$ (Wang and Gonzalez de Mejia, 2005). Previous 
254 thermolysin digestion of myosin protein, both corresponding to MHC. Both peptides also

255 resulted to be antihypertensive in vivo when tested in spontaneous hypertensive rats at a

256 concentration of $1 \mathrm{mg} / \mathrm{kg}$ animal weight, resulting in a decrease in systolic blood pressure

257 of $23.4 \pm 3.0 \mathrm{mmHg}$ and $21.0 \pm 3.1 \mathrm{mmHg}$ after $6 \mathrm{~h}$, respectively (Arihara et al., 2001).

258 On the other hand, the peptide SNAAC derived from MHC 1 and 4 has been reported as

259 the most antioxidant peptide identified to date in Spanish dry-cured ham (Mora et al.,

260 2014). This peptide showed an $\mathrm{IC}_{50}$ value of $75.2 \mu \mathrm{M}$ in $\mathrm{DPPH}$ radical-scavenging assay

261 and $205 \mu \mathrm{M}$ in ferric-reducing antioxidant power analysis, which were similar values to

262 those obtained for the positive control butylated hydroxytoluene (BHT) (Mora et al.,

263 2014). Moreover, a recent study evidenced the stability of this potent antioxidant peptide

264 to different processing conditions and its effectiveness to partially prevent lipid oxidation

265 (Gallego et al., 2018).

266

\section{4. Conclusions}

268 Peptidomic approaches using mass spectrometry in tandem have contributed to an

269 advance in the identification of naturally generated peptides during the processing of meat

270 products. Different myofibrillar proteins have been monitored at the end of the meat dry-

271 curing process and peptides identified. This study shows a total of 23,27 , and 45 peptides

272 from MYH1_PIG, MYH2_PIG, and MYH4_PIG, respectively, whereas only five

273 peptides were identified from MYH7_PIG. The size, sequence, and previously described

274 properties of some of the generated peptides would show the potential of MHC protein

275 as a good source of bioactive peptides.

\section{Acknowledgments}


277 Grant AGL2014-57367-R and FEDER funds from the Spanish Ministry of Economy,

278 Industry and Competitiveness are acknowledged. Ramón y Cajal postdoctoral contract to

279 LM is also acknowledged.

280

\section{$281 \quad$ References}

282 Arihara, K., Nakashima, Y., Mukai, T., Ishikawa, S., \& Itoh, M. (2001). Peptide 283 inhibitors for angiotensin I-converting enzyme from enzymatic hydrolysates of 284 porcine skeletal muscle proteins. Meat Science, 57(32), 319-324.

285 Chang, K.C., da Costa, N., Blackley, R., Southwood, O., Evans, G., Plastow, G., Wood, 286 J.D., \& Richardson, R.I. (2003). Relationships of myosin heavy chain fibre types to 287 meat quality traits in traditional and modern pigs. Meat Science, 64(1), 93-103.

288 Choi, Y.M., Ryu, Y.C., \& Kim, B.C. (2007). Influence of myosin heavy- and light chain 289 isoforms on early postmortem glycolytic rate and pork quality. Meat Science, 76(2), 290 281-288.

291 Corrêa, A.P.F., Daroit, D.J., Fontoura, R., Meira, S.M.M., Segalin,J., \& Brandelli, A. 292 (2014). Hydrolysates of sheep cheese whey as a source of bioactive peptides with 293 antioxidant and angiotensin-converting enzyme inhibitory activities. Peptides, 6, 48294 55.

295 Di Luccia. A., Picariello, G., Cacace, G., Scaloni, A., Faccia, M., Liuzzi, V., Alviti, G., 296 \& Musso, S.S. (2005). Proteomic analysis of water soluble and myofibrillar protein changes occurring in dry-cured hams. Meat Science, 69(3), 479-491.

298 Eggert, J.M., Depreux, F.F.S., Schinckel, A.P., Grant, A.L., Gerrard, D.E. (2002). Myosin 299 heavy chain isoforms account for variation in pork quality. Meat Science, 61(2), 117126. 
301 Escudero, E., Sentandreu, M. A., Arihara, K., \& Toldrá, F. (2010). Angiotensin I302 converting enzyme inhibitory peptides generated from in vitro gastrointestinal 303 digestion of pork meat. Journal of Agricultural and Food Chemistry, 58(5), 2895-2901.

304 Escudero, E., Aristoy, M. C., Nishimura, H., Arihara, K., \& Toldrá, F. (2012). 305 Antihypertensive effect and antioxidant activity of peptide fractions extracted from 306 Spanish dry-cured ham. Meat Science, 91(3), 306-311.

307 Fabbro, A., Bencivenni, M., Piasentier, E., Sforza, S., Stecchini, M. L., \& Lippe, G. 308 (2016). Proteolytic resistance of actin but not of myosin heavy chain during processing 309 of Italian PDO (protected designation of origin) dry-cured hams. European Food $310 \quad$ Research and Technology, 242(6), 881-889.

311 Flores, M., Alasnier, C., Aristoy, M.C., Navarro, J.L., Gandemer, G., \& Toldrá, F. (1996). 312 Activity of aminopeptidase and lipolytic enzymes in five skeletal muscles with various 313 oxidative patterns. Journal of the Science of Food and Agriculture, 70(1), 127-130.

314 Gallego, M., Mora, L., Fraser, P.D., Aristoy, M.C., \& Toldrá, F. (2014). Degradation of 315 LIM domain-binding protein 3 during Spanish dry-cured ham processing. Food $316 \quad$ Chemistry, 149, 121-128.

317 Gallego M, Mora L, Aristoy MC, \& Toldrá F. (2015a). Titin-derived peptides as 318 processing time markers in dry-cured ham. Food Chemistry, 167, 326-339.

319 Gallego, M., Mora, L., Aristoy, M.C., \& Toldrá, F. (2015b). Evidence of peptide 320 oxidation from major myofibrillar proteins in dry-cured ham. Food Chemistry, 187, $321 \quad 230-235$.

322 Gallego, M., Mora, L., Reig, M., \& Toldrá, F. (2018). Stability of the potent antioxidant 323 peptide SNAAC identified from Spanish dry-cured ham. Food Research International, 324 $105,873-879$. 
325 Gianelli, P., Flores, M., Moya, V.J., Aristoy, M.C., \& Toldrá, F. (2000).Effect of carnosine, anserine and other endogenous skeletal peptides on the activity of porcine muscle alanyl and arginyl aminopeptidases. Journal of Food Biochemistry, 24, 69-78.

328

Goll, D.E., Neti, G., Mares, S.W., \& Thompson, V.F. (2008). Myofibrillar protein turnover: the proteasome and the calpains. Journal of Animal Science. 86(14), 19-35.

Hirao, T., Hara, K., \& Takahashi, K. (1984). Purification and characterization of cathepsin-B from monkey skeletal-muscle. Journal of Biochemistry,95(3), 871-879.

Kang, Y.K., Choi, Y.M., Lee, S.H., Choe, J.H., Hong, K.C., \& Kim, B.C. (2011). Effects of myosin heavy chain isoforms on meat quality, fatty acid composition, and sensory evaluation in Berkshire pigs. Meat Science, 89(4), 384-389.

Katayama, K., Fuchu, H., Sakata, A., Kawahara, S., Yamauchi, K., Kawamura, Y., \& Muguruma, M. (2003). Angiotensin I-converting enzyme inhibitory activities of porcine skeletal muscle proteins following enzyme digestion. Asian-Australasian Journal of Animal Sciences, 16(3), 417-424.

Korhonen, H., \& Pihlanto, A. (2003). Food-derived bioactive peptides-opportunities for designing future foods. Current Pharmaceutical Design, 9(16), 1297-1308.

Lan, V.T.T., Ito, K., Ohno, M., Motoyama, T., Ito, S., \& Kawarasaki, Y. (2015). Analyzing a dipeptide library to identify human dipeptidyl peptidase IV inhibitor. Food Chemistry, 175, 66-73.

Leseigneur-Meynier, A., \& Gandemer, G. (1991). Lipid-composition of pork muscle in relation to the metabolic type of the fibers. Meat Science, 29(3), 229-241.

Mohanty, D.P., Mohapatra, S., Misra, S., \& Sahu, P.S. (2016). Milk derived bioactive peptides and their impact on human health e a review. Saudi Journal of Biological Sciences, 23(5), 577-583. 
Mora, L., Sentandreu, M.A., Koistinen, K.M., Fraser, P.D., Toldrá, F., \& Bramley, P.M. 350 (2009a). Naturally generated small peptides derived from myofibrillar proteins in 351 Serrano dry-cured ham. Journal of Agricultural and Food Chemistry, 57, 3228-3234.

352 Mora, L., Sentandreu, M.A., Fraser, P.D., Toldrá, F., \& Bramley, P.M. (2009b). 353 Oligopeptides arising the degradation of creatine kinase in Spanish dry-cured ham. $354 \quad$ Journal of Agricultural and Food Chemistry, 57, 8982-8988.

355 Mora, L., Sentandreu, M.A., \& Toldrá, F. (2010). Identification of small troponin T 356 peptides generated in dry-cured ham. Food Chemistry, 123, 691-697.

357 Mora, L., Sentandreu, M.A., \& Toldrá, F. (2011a). Intense degradation of myosin light 358 chain isoforms in Spanish dry-cured ham. Journal of Agricultural and Food Chemistry, $359 \quad 59,3884-3892$.

360 Mora, L., Valero, M.L., Del Pino, M.M.S., Sentandreu, M.A., \& Toldrá, F. (2011b). Small 361 peptides released from muscle glycolytic enzymes during dry-cured ham processing. 362 Journal of Proteomics, 74, 442-450.

363 Mora, L., \& Toldrá, F. (2012). Proteomic identification of small (<2000 Da) myoglobin 364 peptides generated in dry-cured ham. Food Technology and Biotechnology, 50(3), $365 \quad 343-349$.

366 Mora, L., Escudero, E., Fraser, P. D., Aristoy, M. C., \& Toldrá, F. (2014). Proteomic 367 identification of antioxidant peptides from 400 to 2500Da generated in Spanish dry368 cured ham contained in a size-exclusion chromatography fraction. Food Research 369 International, 56, 68-76.

370 Mora, L., Gallego, M., Aristoy, M.C., Fraser, P.D., \& Toldrá, F. (2015a). Peptides 371 naturally generated from ubiquitin-60S ribosomal protein as potential biomarkers of 372 dry-cured ham processing time. Food Control, 48, 102-107. 
373 Mora, L., Escudero, E., Arihara, K. \& Toldrá, F. (2015b). Antihypertensive effect of 374 peptides naturally generated during Iberian dry-cured ham processing. Food Research $375 \quad$ International, 78, 71-78.

376 Mora, L., Escudero, E., \& Toldrá, F. (2016). Characterization of the peptide profile in 377 Spanish Teruel, Italian Parma and Belgian dry-cured hams and its potential bioactivity. $378 \quad$ Food Research International, 89, 638-646.

379 Mora, L., Bolumar, T., Heres, A., \& Toldrá, F. (2017). Effect of cooking and simulated 380 gastrointestinal digestion of aged beef meat on the activity of generated bioactive 381 peptides. Food \& Function, 8, 4347-4355.

382 Picariello, G., De Martino, A., Mamone, G., Ferranti, P., Addeo, F., Faccia, M., 383 SpagnaMusso, S., \& Di Luccia, A. (2006). Proteomic study of muscle sarcoplasmic 384 proteins using AUT-PAGE/SDS-PAGE as two-dimensional gel electrophoresis. 385 Journal of Chromatography B, 833, 101-108.

386 Rico, E., Toldrá, F., \& Flores, J. (1991). Assay of cathepsin D activity in fresh pork 387 muscle and dry-cured ham. Meat Science, 29, 287-293.

388 Schiaffino, S., \& Reggiani, C. (1996). Molecular diversity of myofibrillar proteins: gene 389 regulation and functional significance. Physiological Reviews, 76, 371-423.

390 Sentandreu, M.A., \& Toldrá, F. (2001). Dipeptidylpeptidase activities along the 391 processing of Serrano dry-cured ham. European Food Research and Technology, 213, $392 \quad 83-87$.

393 Sentandreu, M.A., Stoeva, S., Aristoy, M.C., Laib, K., Voelter, W., \& Toldrá, F. (2003). 394 Identification of taste related peptides in Spanish Serrano dry-cured hams. Journal of 395 Food Science, 68, 64-69 
Sentandreu, M.A., Armenteros, M., Calvete, J.J., Ouali, A., Aristoy, M.C., \& Toldrá, F. (2007). Proteomic identification of actin-derived oligopeptides in dry-cured ham. Journal of Agricultural and Food Chemistry, 55(9), 3613-3619.

Toldrá, F., Rico, E., \& Flores, J. (1993). Cathepsin-B, cathepsin-D, cathepsin-H and cathepsin-1 activities in the processing of dry-cured ham. Journal of the Science of Food and Agriculture, 62, 157-161.

Toldrá, F. (1998). Proteolysis and lipolysis in flavour development of dry-cured meat products. Meat Science, 49, S101-S110.

Toldrá F, \& Flores M. (1998). The role of muscle proteases and lipases in flavor development during the processing of dry-cured ham. Critical Reviews in Food Science and Nutrition, 38, 331-352.

Toldrá, F., Aristoy, M.C., \& Flores, M. (2000). Contribution of muscle aminopeptidases to flavor development in dry-cured ham. Food Research International, 33, 181-185.

Toldrá, F. (2002). Dry-cured meat products. Ames, IO: Wiley-Blackwell. ISBN: 9780917678547.

Toldrá, F. (2006). The role of muscle enzymes in dry-cured meat products with different drying conditions. Trends in Food Science \& Technology, ., 17, 164-168.

Toldrá, F., \& Reig, M. (2015). The biochemistry of meat and fat. In F. Toldrá, Y.H. Hui, I. Astiasarán, J.G. Sebranek, R. Talon, (Eds.), Handbook of Fermented Meat and Poultry. Ames, IO: Wiley-Blackwell. p. 49-54.

Wang, W., \& Gonzalez de Mejia, E. (2005). A new frontier in soy bioactive peptides that may prevent age-related chronic diseases. Comprehensive Reviews in Food Science and Food Safety, 4, 63-77. 


\section{SUPPLEMENTARY MATERIAL}

Figure 1. MHC isoforms of mammal skeletal muscles. The three fast (2a, 2x, and 2b) isoforms and the slow (1) isoform, that correspond to UniProt database entry names MYH1 (Q9TV61), MYH2 (Q9TV63), MYH4 (Q9TV62), and MYH7 (P79293), respectively. Grey shadow shows the identified fragments in this study.

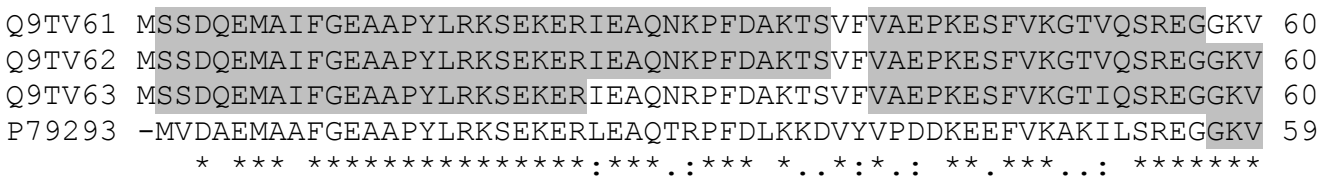

Q9TV61 TVKTEAGATLTVKEDQVFPMNPPKEDKIEDMAMMTHLHEPAVLYNLKERYAAWMIYTYSG 120 Q9TV62 TVKTEAGATLTVKEDQVFPMNPPKEDKIEDMAMMTHLHEPAVLYNLKERYAAWMIYTYSG 120 Q9TV63 TVKTEAGATLTVKEDQVFPMNPPKFDKIEDMAMMTHLHEPGVLYNLKERYAAWMIYTYSG 120 P79293 TAETEHGKTVTVKEDQVLQQNPPKFDKIEDMAMLTFLHEPAVLYNLKERYASWMIYTYSG 119

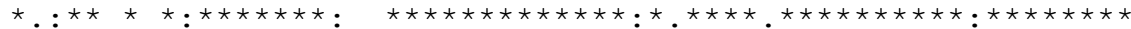

Q9TV61 LFCVTVNPYKWLPVYNAEVVTAYRGKKRQEAPPHIFS ISDNAYQFMLTDRENQS ILITGE 180 Q9TV62 LFCVTVNPYKWLPVYNAEVVTAYRGKKRQEAPPHIFS ISDNAYQFMLTDRENQSILITGE 180 Q9TV63 LFCVTVNPYKWLPVYNPEVVTAYRGKKRQEAPPHIFSISDNAYQFMLTDRENQS ILITGE 180 P79293 LFCVTINPYKWLPVYNAEVVAAYRGKKRSEAPPHIFS ISDNAYQYMLTDRENQSILITGE 179

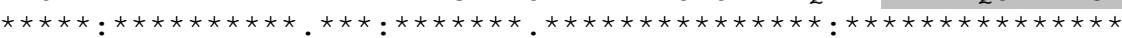

Q9TV61 SGAGKTVNTKRVIQYFATIAVTGEKKKEEPTSGKMQGTLEDQIISANPLLEAFGNAKTVR 240 Q9TV62 SGAGKTVNTKRVIQYFATIAVTGEKKKEEPTPGKMQGTLEDQI I SANPLLEAFGNAKTVR 240 Q9TV63 SGAGKTVNTKRVIQYFATIAVTGEKKKEEPTSGKMQGTLEDQIISANPLLEAFGNAKTVR 240 P79293 SGAGKTVNTKRVIQYFAVIAAIGDRSKKEQTPG--KGTLEDQIIQANPALEAFGNAKTVR 237

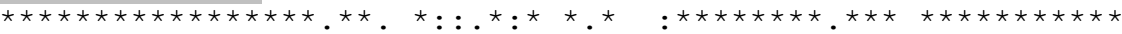

Q9TV61 NDNSSRFGKFIRIHFGTTGKLASADIETYLLEKSRVTFQLKAERSYHIFYQIMSNKKPEL 300 Q9TV62 NDNSSRFGKFIRIHFGTTGKLASADIETYLLEKSRVTFQLKAERSYHIFYQIMSNKKPEL 300 Q9TV63 NDNSSRFGKFIRIHFGTTGKLASADIETYLLEKSRVTFQLKAERSYHIFYQITSNRKPEL 300 P79293 NDNSSRFGKFIRIHFGATGKLASADIETYLLEKSRVIFQLKAERDYHIFYQILSNKKPEL 297

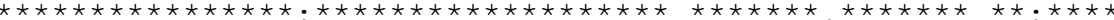

Q9TV61 IEMLLITTNPYDYAFVSQGEITVPSIDDQEELMATDSAIEILGFTSDERVSIYKLTGAVM 360 Q9TV62 IEMLLITTNPYDYAFVSOGEITVPSIDDQEELMATDSAIEILGFTSDERVSIYKLTGAVM 360 Q9TV63 IEMLLITTNPYDYPFISQGEISVASIDDQEELIATDSAIDILGFTNEEKVSIYKLTGAVM 360 P79293 LDMLLITNNPYDYAFISQGETTVASIDDAEELMATDNAFDVLGFTSEEKNSMYKLTGAIM 357

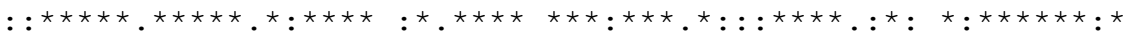

Q9TV61 HYGNLKEKQKQREEQAEPDGTEVADKAAYLQGLNSADLLKALCYPRVKVGNEFVTKGQTV 420 Q9TV62 HYGNLKFKQKQREEQAEPDGTEVADKAAYLQGLNSADLLKALCYPRVKVGNEFVTKGQTV 420 Q9TV63 HYGNLKEKQKQREEQAEPDGTEVADKAAYLQSLNSADLLKALCY PRVKVGNEYVTKGQTV 420 P79293 HFGNMKFKLKOREEQAEPDGTEEADKSAYLMGLNSADLLKGLCHPRVKVGNEYVTKGQNV 417

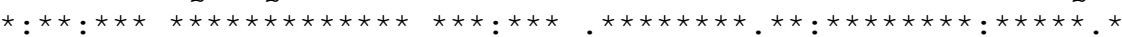

Q9TV61 QOVYNAVGALAKAVYDKMFLWMVTRINQQLDTKOPROYFIGVLDIAGFEIFDFNSLEOLC 480 Q9TV62 QQVYNAVGALAKAVYDKMFLWMVTRINQQLDTKQPRQYFIGVLDIAGFEIFDFNSLEQLC 480 Q9TV63 EQVTNAVGALAKAVYEKMFLWMVTRINQQLDTKQPROYFIGVLDIAGFEIFDFNSLEQLC 480 P79293 QQVMYATGALAKAVYEKMFNWMVTRINTTLETKQPRQYFIGVLDIAGFEIFDFNSFEQLC 477

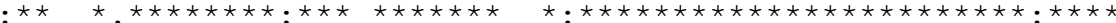

Q9TV61 INFTNEKLQQFFNHHMFVLEQEEYKKEGIEWEFIDFGMDLAACIELIEKPMGIFS ILEEE 540 Q9TV62 INFTNEKLQQFFNHHMFVLEQEEYKKEGIEWEFIDFGMDLAACIELIEKPMGIFSILEEE 540 Q9TV63 INFTNEKLQQFFNHHMFVLEQEEYKREGIEWTFIDFGMDLAACIELIEKPMGIFS ILEEE 540 P79293 INFTNEKLQQFFNHHMFVLEQEEYKKEGIEWEFIDFGMDLQACIDLIEKPMGIMS ILEEE 537

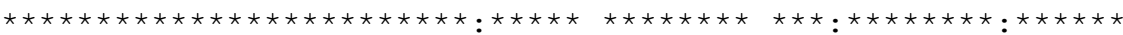

Q9TV61 CMFPKATDTSFKNKLYEQHLGKSNNFQKPKPAKGKVEAHFSLIHYAGTVDYNITGWLDKN 600 Q9TV62 CMFPKATDTSFKNKLYEQHLGKSNNFQKPKPAKGKAEAHFSLIHYAGTVDYNITGWLDKN 600 Q9TV63 CMFPKATDTSFKNKLYEQHLGKSANFQKPKPAKGKVEAHFSLIHYAGTVDYNITGWLDKN 600 
P79293 CMFPKATDMTFKAKLYDNHLGKSNNFOKPRNIKGRPEAHFALIHYAGTVDYNIIGWLQKN 597

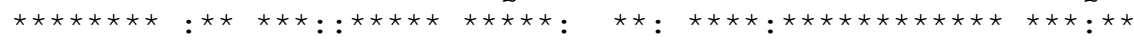

Q9TV61 KDPLNETVVGLYQKSSVKTLAFLFTGAAGADAEAGGGKKGGKKKGSSFQTVSALFRENLN 660 Q9TV62 KDPLNETVVGLYQKSSVKTLAFLFAERQ--SSEEGGTKKGGKKKGSSFQTVSALFRENLN 658 Q9TV63 KDPLNDTVVGLYQKSALKTLAFLFSGAQTGEAEAGGTKKGGKKKGSSFQTVSALFRENLN 660 P79293 KDPLNETVVDLYKKSSLKLLSNLFANYAGADTPVEKGK-GKAKKGSSFQTVSALHRENLN 656

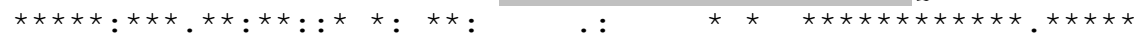

Q9TV61 KLMTNLRSTHPHFVRCIIPNETKTPGAMEHELVLHQLRCNGVLEGIRICRKGFPSRILYA 720 Q9TV62 KLMTNLRSTHPHFVRCI IPNETKTPGAMEHELVLHQLRCNGVLEGIRICRKGFPSRILYA 718 Q9TV63 KLMTNLRSTHPHFVRCI IPNETKTPGAMEHELVLHQLRCNGVLEGIRICRKGFPSRILYA 720 P79293 KLMTNLRSTHPHFVRCIIPNETKSPGVIDNPLVMHQLRCNGVLEGIRICRKGFPNRILYG 716

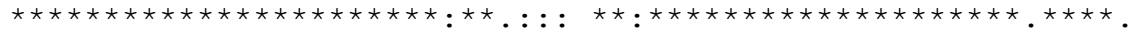

Q9TV61 DFKQRYKVLNASAIPEGQFIDSKKASEKLLGSIDIDHTQYKFGHTKVFFKAGLLGLLEEM 780 Q9TV62 DFKQRYKVLNASAIPEGQFIDSKKASEKLLGS IDIDHTQYKFGHTKVFFKAGLLGTLEEM 778 Q9TV63 DFKQRYKVLNASAIPEGQYIDSKKASEKLLAS IDIDHTQYKFGHTKVFFKAGLLGLLEEM 780 P79293 DFRQRYRILNPAAI PEGQFIDSRKGAEKLLGSLDIDHNQYKFGHTKVFFKAGLLGLLEEM 776

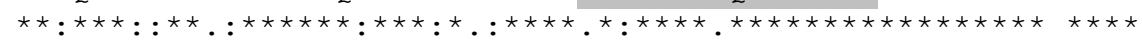

Q9TV61 RDEKLAQLITRTQARCRGFLARVEYQKMVERRESIFCIQYNIRAFMNVKHWPWMKLYFKI 840 Q9TV62 RDEKLAQLITRTQAMCRGFLMRVEFRKMMERRESIFCIQYNIRAFMNVKHWPWMKLYFKI 838 Q9TV63 RDDKLAQLITRTQARCRGFLARVEYQKMVERRESIFCIQYNIRAFMNVKHWPWMKLFFKI 840 P79293 RDERLSRIITRIQAQSRGVLSRMEFKKLLERRDSLLIIQWNIRAFMSVKNWPWMKLYFKI 836

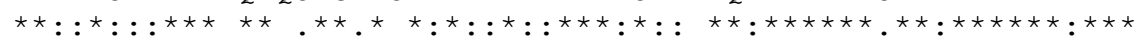

Q9TV61 KPLLKSAETEKEMANMKEEFEKTKESLAKAEAKRKELEEKMVALMQEKNDLQLQVQAEAD 900 Q9TV62 KPLLKSAETEKEMANMKEEFEKTKEDLAKSEAKRKELEEKMVALMQEKNDLQLQVQAEAD 898 Q9TV63 KPLLKSAESEKEMATMKEEFQKTKDELAKSEAKRKELEEKMVTLLKEKNDLQLQVQAEAE 900 P79293 KPLLKSAETEKEMATMKEEFGRLKEALEKSEARRKELEEKMVSLLQEKNDLQLQVQAEQD 896

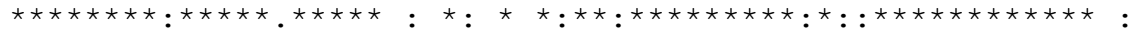

Q9TV61 SLADAEERCDQLIKTKIQLEAKIKEVTERAEDEEEINAELTAKKRKLEDECSELKKDIDD 960 Q9TV62 GLADAEERCDQLIKTKIQLEAKIKEVTERAEDEEEINAELTAKKRKLEDECSELKKDIDD 958 Q9TV63 GLADAEERCDQLIKTKIQLEAKIKEVTERAEDEEEINAELTAKKRKLEDECSELKKDIDD 960 P79293 NLADAEERCDQLIKNKIQLEAKVKEMTERLEDEEEMNAELTAKKRKLEDECSELKRDIDD 956

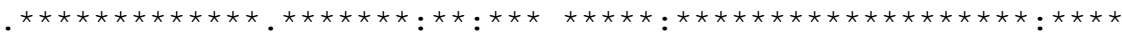

Q9TV61 LELTLAKVEKEKHATENKVKNLTEEMAGLDETIAKLTKEKKALQEAHQQTLDDLQAEEDK 1020 Q9TV62 LELTLAKVEKEKHATENKVKNLTEEMAGLDENIAKLTKEKKALQEAHQQTLDDLQAEEDK 1018 Q9TV63 LELTLAKVEKEKHATENKVKNLTEEMAGLDETIAKLTKEKKALQEAHQQTLDDLQAEEDK 1020 P79293 LELTLAKVEKEKHATENKVKNLTEEMAGLDEI IAKLTKEKKALQEAHQQALDDLQAEEDK 1016

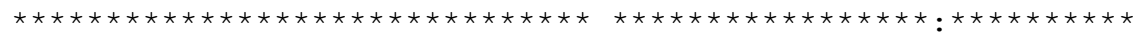

Q9TV61 VNTLTKAKTKLEQQVDDLEGSLEQEKKLRMDLERAKRKLEGDLKLAQESTMDIENDKQQL 1080 Q9TV62 VNTLTKAKTKLEQQVDDLEGSLEQEKKLRMDLERAKRKLEGDLKLAQESTMDIENDKQQL 1078 Q9TV63 VNTLTKAKTKLEQQVDDLEGSLEQEKKLRMDLERAKRKLEGDLKLAQES IMDIENEKQQL 1080 P79293 VNTLTKAKVKLEQHVDDLEGSLEQEKKVRMDLERAKRKLEGDLKLTQES IMDLENDKQQL 1076 $* * * * * * * * . * * * *: * * * * * * * * * * * * *: * * * * * * * * * * * * * * * * *: * * * * *: * *: * * * *$

Q9TV61 DEKLKKKEFEMSNLQSKIEDEQALAMQLQKKIKELQARIEELEEEIEAERASRAKAEKQR 1140 Q9TV62 DEKLKKKEFEMSNLQSKIEDEQALAMQLQKKIKELQARTEELEEEIEAERASRAKAEKQR 1138 Q9TV63 DEKLKKKEFEISNLQSKIEDEQALAIQLQKKIKELQARIEELEEEIEAERASRAKAEKQR 1140 P79293 DERLKKKDFELNALNARIEDEQALGSQLQKKLKELQARIEELEEELEAERTARAKVEKLR 1136

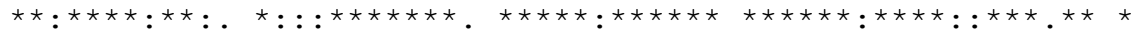

Q9TV61 SDLSRELEEISERLEEAGGATSAQIEMNKKREAEFQKMRRDLEEATLQHEATAATLRKKH 1200 Q9TV62 SDLSRELEEISERLEEAGGATSAQIEMNKKREAEFQKMRRDLEEATLQHEATAAALRKKH 1198 Q9TV63 SDLSRELEEISERLEEAGGATSAQIEMNKKREAEFQKMRRDLEEATLQHEATAAALRKKH 1200 P79293 SDLSRELEEISERLEEAGGATSVQIEMNKKREAEFQKMRRDLEEATLQHEATAAALRKKH 1196

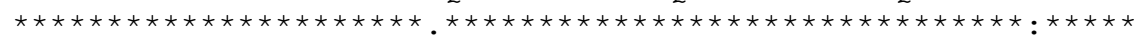

Q9TV61 ADSVAELGEQIDNLQRVKQKLEKEKSEMKMEIDDLASNMETVSKAKGNLEKMCRTLEDQL 1260 Q9TV62 ADSVAELGEQIDNLQRVKQKLEKEKSELKMEIDDLASNMETVSKAKGNLEKMCRTLEDQL 1258 Q9TV63 ADSVAELGEQIDNLQRVKQKLEKEKSEMKMEIDDLASNMETVSKAKGNLEKMCRTLEDQL 1260 P79293 ADSVAELGEQIDNLQRVKQKLEKEKSEFKLELDDVTSNMEQI IKAKANLEKMCRTLEDQM 1256

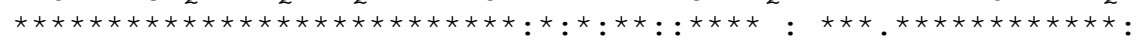


Q9TV61 SELKTKEEEQQRLINDLTAQRARLQTESGEYSRQLDEKDTLVSQLSRGKQAFTQQIEELK 1320 Q9TV62 SEVKTKEEEHQRLINELSAQKARLQTESGEFSRQLDEKEALVSQLSRGKQAFTQQIEELK 1318 Q9TV63 SELKSKEEEQQRLINDLTAQRGRLQTESGEFSRQLDEKEALVSQLSRGKQAYTQQIEELK 1320 P79293 NEHRSKAEETQRSVNDLTSQRAKLQTENGELSRQLDEKEALISQLTRGKLTYTQQLEDLK 1316

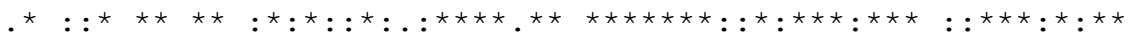

Q9TV61 RQLEEEIKAKSALAHAVQSSRHDCDLLREQYEEEQEAKAELQRAMSKANSEVAQWRTKYE 1380 Q9TV62 RQLEEETKAKSALAHAVQSSRHDCDLLREQYEEEQEAKAELQRAMSKANSEVAQWRTKYE 1378 Q9TV63 RQLEEEIKAKNALAHALQSSRHDCDLLREQYEEEQESKAELQRALSKANTEVAQWRTKYE 1380 P79293 RQLEEEVKAKNALAHALQSARHDCDLLREQYEEETEAKAELQRVLSKANSEVAQWRTKYE 1376

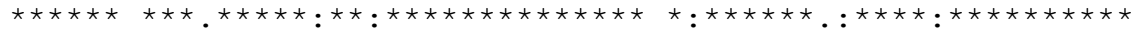

Q9TV61 TDAIQRTEELEEAKKKLAQRLQDAEEHVEAVNAKCASLEKTKQRLQNEVEDLMIDVERSN 1440 Q9TV62 TDAIQRTEELEEAKKKLAQRLQDAEEHVEAVNAKCASLEKTKQRLQNEVEDLMLDVERSN 1438 Q9TV63 TDAIQRTEELEEAKKKLAQRLQAAEEHVEAVNAKCASLEKTKQRLQNEVEDLMLDVERTN 1440 P79293 TDAIQRTEELEEAKKKLAQRLQDAEEAVEAVNAKCSSLEKTKHRLQNEIEDLMVDVERSN 1436

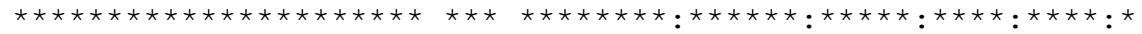

Q9TV61 AACAALDKKQRNFDKILAEWKQKYEETHAELEASQKESRSLSTELFKVKNAYEESLDQLE 1500 Q9TV62 AACAALDKKQRNFDKI LAEWKHKYEETQAELEASQKESRSLSTELFKVKNAYEESLDQLE 1498 Q9TV63 AACAALDKKQRNFDKILAEWKQKYEETHAELEASQKEARS LGTELFKMKNAYEESLDQLE 1500 P79293 AAAAALDKKQRNFDKILAEWKQKYEESQSELESSQKEARSLSTELFKLKNAYEESLEHLE 1496

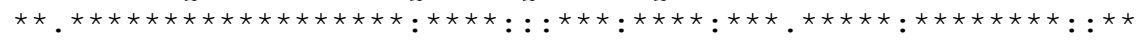

Q9TV61 TLKRENKNLQQEISDLTEQIAEGGKRIHELEKIKKQVEQEKSEIQAALEEAEASLEHEEG 1560 Q9TV62 TLKRENKNLQQEISDLTEQIAEGGKHIHELEKVKKQIEQEKSELQAALEEAEASLEHEEG 1558 Q9TV63 TLKRENKNLQQEISDLTEQIAEGGKRIHELEKIKKQVEQEKSEIQAALEEAEASLEHEEG 1560 P79293 TFKRENKNLQEEISDLTEQLGSSGKTIHELEKVRKQLEAEKLELQSALEEAEASLEHEEG 1556

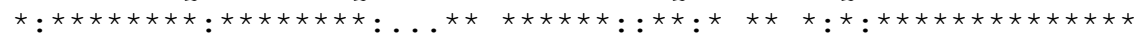

Q9TV61 KILRIQLELNQVKSEVDRKIAEKDEEIDQLKRNHVRVVESMQSMLDAEIRSRNDAIRLKK 1620 Q9TV62 KILRIQLELNQVKSEIDRKIAEKDEEIDQMKRNHIRVVESMQSTLDAEIRSRNDALRIKK 1618 Q9TV63 KILRIQLELNQVKSEVDRKIAEKDEEIDQLKRNHVRVVESMQSMLDAEIRSRNDAIRLKK 1620 P79293 KILRAQLEFNQIKAEMERKLAEKDEEMEQAKRNHLRVVDSLQTSLDAETRSRNEALRVKK 1616

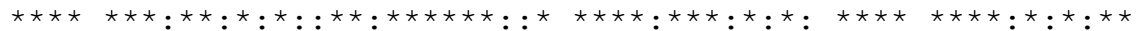

Q9TV61 KMEGDLNEMEIQLNHANRMAAEALRNYRNTQGILKDTQIHLDDALRSQEDLKEQLAMVER 1680 Q9TV62 KMEGDLNEMEIQLNHANRQATEAIRNLRNTQGVLKDTQLHLDDAIRGQDDLKEQLAMVER 1678 Q9TV63 KMEGDLNEMEIQLNHANRMAAEALRNYRNTQGILKDTQIHLDDALRGQEDLKEQLAMVER 1680 P79293 KMEGDLNEMEIQLSHANRMAAEAQKQVKSLQSLLKDTQIQLDDAVRANDDLKENIAIVER 1676

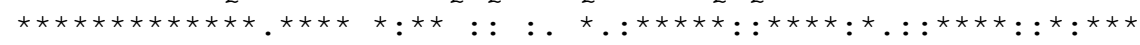

Q9TV61 RANLLQAEIEELRATLEQTERSRKVAEQELLDASERVQLLHTQNTSLINTKKKLETDISQ 1740 Q9TV62 RANLMQAEIEELRASLEQTERSRRVAEQELLDASERVQLLHTQNTSLINTKKKLETDISQ 1738 Q9TV63 RANLLQAEIEELRATLEQTERSRKVAEQELLDASERVQLLHTQNTSLINTKKKLETDISQ 1740 P79293 RNNLLQAELEELRAVVEQTERSRKLAEQELIETSERVQLLHSQNTSLINQKKKMEADLSQ 1736

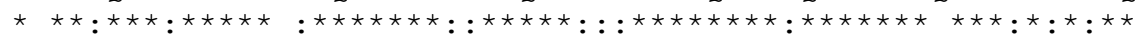

Q9TV61 IQGEMEDIIQEARNAEEKAKKAITDAAMMAEELKKEQDTSAHLERMKKNLEQTVKDLQHR 1800 Q9TV62 IQGEMEDIVQEARNAEEKAKKAITDAAMMAEELKKEQDTSAHLERMKKNMEQTVKDLQHR 1798 Q9TV63 MQGEMEDILQEARNAEEKAKKAITDAAMMAEELKKEQDTSAHLERMKKNMEQTVKDLQHR 1800 P79293 LQTEVEEAVQECRNAEEKAKKAITDAAMMAEELKKEQDTSAHLERMKKNMEQTIKDLQHR 1796

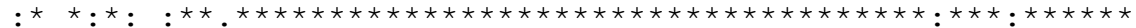

Q9TV61 LDEAEQLALKGGKKQIQKLEARVRELEGEVESEQKRNVETVKGLRKHERRVKELTYQTEE 1860 Q9TV62 LDEAEQLALKGGKKQIQKLEARVRELENEVENEQKRNVEAVKGLRKHERRVKELTYQTEE 1858 Q9TV63 LDEAEQLALKGGKKQIQKLEARVRELEGEVESEQKRNAEAVKGLRKHERRVKELTYQTEE 1860 P79293 LDEAEQIALKGGKKQLQKLEARVRELENELEAEQKRNAESVKGMRKSERRIKELTYQTEE 1856

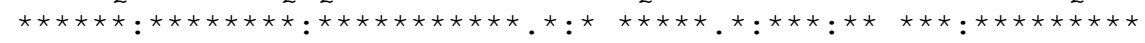

Q9TV61 DRKNILRLQDLVDKLQAKVKSYKRQAEEAEEQSNVNLSKFRKLQHELEEAEERADIAESQ 1920 Q9TV62 DRKNVLRLQDLVDKLQSKVKAYKRQAEEAEEQSNVNLSKFRKLQHELEEAEERADIAESQ 1918 Q9TV63 DRKNILRLQDLVDKLQAKVKSYKRQAEEAEEQSNTNLSKFRKLQHELEEAEERADIAESQ 1920 P79293 DRKNLLRLQDLVDKLQLKVKAYKRQAEEAEEQANTNLSKFRKVQHELDEAEERADIAESQ 1916

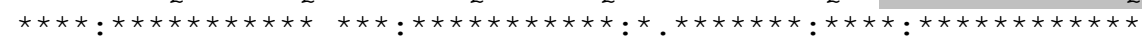


Q9TV62 VNKLRVKSREVHTKVISEE 1937

Q9TV63 VNKLRVKSREVHTKVISEE 1939

P79293 VNKLRAKSRDIGTKGLNEE 1935

$\star \star \star \star \star . * \star \star:: * \star: . * \star$ 
Table 1. Peptides naturally generated during the processing of dry-cured ham identified using mass spectrometry in tandem and sequences of the most probable di- and tripeptides generated according with the peptidases action and the identified peptides.

\begin{tabular}{|c|c|c|c|}
\hline Protein Name & $\begin{array}{l}\text { Identified } \\
\text { Peptides }\end{array}$ & $\begin{array}{l}\text { Elucidated di- and tripeptides from } \\
\text { the identified sequences }\end{array}$ & References \\
\hline Actin (ACT) & 4 & - & Sentandreu et al. (2007) \\
\hline & 9 & $\mathrm{AA}, \mathrm{PA}$ & Mora et al. (2011a) \\
\hline Myosin Light Chain 1 (MLC 1) & 137 & $\begin{array}{l}\text { AP, IE, PAP, EEM, NP, LG, VK, NAE, } \\
\text { TN, TNP, VF, RVF, AL }\end{array}$ & Mora et al. (2009a) \\
\hline Myosin Light Chain 2 (MLC 2) & 88 & $\begin{array}{l}\text { RD, LR, IN, SGP, IK, VLD, FK, PE, } \\
\text { KV, AD, LKG, EK, EKL }\end{array}$ & Mora et al. (2011a) \\
\hline Titin (TTN) & $\begin{array}{c}5 \\
320\end{array}$ & $\begin{array}{l}\text { KV } \\
\text { EP, SV, SVL, RKK, PK, PKE, AK, } \\
\text { AKK, VE, KA, TPK, KAV, EE, EP, } \\
\text { PA, EI, KER, PE, KP, EPE, VK, PPI, } \\
\text { PTP, KA, PP, EA, KDE, KAV, EAK, } \\
\text { GP, IKG, PSP, IEA, APF, DE, VKF, } \\
\text { DEI, DAV, STS, MLK }\end{array}$ & $\begin{array}{l}\text { Picariello et al. (2006) } \\
\text { Gallego et al. (2015a) }\end{array}$ \\
\hline Creatine kinase (CK) & 58 & $\begin{array}{l}\text { DL, LA, VS, VE, GHP, HKT, YV, PD, } \\
\text { VQ, SVF, AQK }\end{array}$ & Mora et al. (2009b) \\
\hline Slow Troponin T $(\mathrm{TnT})$ & 2 & NK & Mora et al. (2010) \\
\hline Fast Troponin T (TnT) & 25 & $\mathrm{NK}, \mathrm{IP}, \mathrm{AP}$ & Mora et al. (2010) \\
\hline Glycogen phosphorylase (PYGM) & 2 & 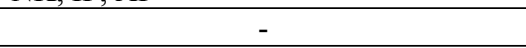 & Mora et al. (2011b) \\
\hline $\begin{array}{l}\text { Glyceraldehyde 3-phosphate } \\
\text { dehydrogenase (GAPDH) }\end{array}$ & 8 & CLA, VK & Mora et al. (2011b) \\
\hline Phosphoglycerate kinase 1 (PGK) & 4 & - & Mora et al. (2011b) \\
\hline Phosphoglycerate mutase 2 (PGAM) & 7 & VRK & Mora et al. (2011b) \\
\hline Enolase (ENO) & 18 & RDG, VY, LYK & Mora et al. (2011b) \\
\hline Piruvate kinase 3 isoform 2 (PK) & $\begin{array}{l}2 \\
1\end{array}$ & 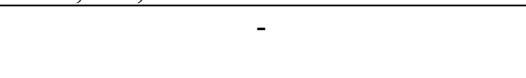 & Mora et al. (2011b) \\
\hline Lactate dehydrogenase (LDH) & 4 & LL & Mora et al. (2011b) \\
\hline LIM domain-binding 3 (LDB3) & 107 & $\begin{array}{l}\text { SVT, GKD, QG, RL, WGF, VV, SQ, } \\
\text { AQ, MP, AQS, QL, SQG, NMP, LT, } \\
\text { IS, LS, EAQ, SA, APA, PA, QP, STY, } \\
\text { AY, QG, GD, SQ, SQL, AL }\end{array}$ & Gallego et al. (2014) \\
\hline Myoglobin (MYO) & 11 & FK, KH, TPL & Mora and Toldrá (2012) \\
\hline Ubiquitin-60S (UBI) & 68 & $\begin{array}{l}\text { VKT, IF, SD, SDY, VK, IFA, DK, KA, } \\
\text { KIQ, DKE, RT, GRT }\end{array}$ & Mora et al. (2015a) \\
\hline
\end{tabular}


Table 2. Myosin Heavy Chain isoforms 1, 2x, 2a and 2b. A) Percentage of homology between the isoforms. B) Accession number and definition of the different isoforms according to the main free access databases Uniprot and NCBInr.

A)

\begin{tabular}{l|c|c|c|c|} 
& \multicolumn{1}{c}{ MYH1_PIG } & MYH2_PIG & \multicolumn{1}{c}{ MYH4_PIG } & \multicolumn{1}{c}{ MHY7_PIG } \\
MHC2x & MHC2a & MHC2b & MHC1 \\
\cline { 2 - 5 } MYH1_PIG & $100 \%$ & $96.0 \%$ & $96.5 \%$ & $81.7 \%$ \\
\cline { 2 - 5 } MYH2_PIG & $96.0 \%$ & $100 \%$ & $94.2 \%$ & $81.8 \%$ \\
\cline { 2 - 5 } MYH4_PIG & $96.5 \%$ & $94.2 \%$ & $100 \%$ & $81.8 \%$ \\
\cline { 2 - 5 } MHY7_PIG & $81.7 \%$ & $81.8 \%$ & $81.8 \%$ & $100 \%$ \\
\cline { 2 - 5 } & & &
\end{tabular}

B)

\begin{tabular}{|c|c|c|c|c|}
\hline \multirow{2}{*}{ Protein name } & \multicolumn{2}{|c|}{ UniProt database } & \multicolumn{2}{|r|}{ NCBInr database } \\
\hline & Accession & Definition & Accession & Definition \\
\hline \multirow[t]{3}{*}{ Myosin heavy chain 1} & Q9TV61 & MYH1_PIG & gi|75056480 & Myosin heavy chain, skeletal muscle, adult 1 \\
\hline & & & gi|5360750 & Myosin heavy chain 2x [Sus scrofa] \\
\hline & & & gi|157279731 & Myosin-1 [Sus scrofa] \\
\hline \multirow[t]{3}{*}{ Myosin heavy chain 2} & Q9TV63 & MYH2_PIG & gi|75056482 & Myosin heavy chain, skeletal muscle, adult 2 \\
\hline & & & gi|5360746 & Myosin heavy chain 2a [Sus scrofa] \\
\hline & & & gi|55741490 & Myosin-2 [Sus scrofa] \\
\hline \multirow[t]{3}{*}{ Myosin heavy chain 4} & Q9TV62 & MYH4_PIG & gi|75056481 & Myosin heavy chain, skeletal muscle, fetal \\
\hline & & & gi|5360748 & Myosin heavy chain $\mathbf{2 b}$ [Sus scrofa] \\
\hline & & & gi| 178056718 & Myosin-4 [Sus scrofa] \\
\hline \multirow[t]{3}{*}{ Myosin heavy chain 7} & P79293 & MHY7_PIG & gi|55741486 & Myosin-7 [Sus scrofa] \\
\hline & & & gi| 125987844 & Myosin heavy chain slow isoform [Sus scrofa] \\
\hline & & & gil 1698895 & Beta-myosin heavy chain [Sus scrofa] \\
\hline
\end{tabular}


Table 3. Myosin heavy chain peptides identified in 9 months Spanish dry-cured ham corresponding to the different isoforms.

\begin{tabular}{|c|c|c|c|c|c|c|c|c|c|c|c|}
\hline Position $^{\mathrm{a}}$ & Identified sequence & Modifications $^{\mathbf{b}}$ & & Exp. $^{d}$ & Ch. & & & \multicolumn{4}{|c|}{ MYHg } \\
\hline & & & $(\mathbf{m} / \mathbf{z})$ & $(\mathbf{m} / \mathbf{z})$ & $(+)$ & $(\mathbf{M W})$ & $(\%)$ & 1 & 2 & 4 & 7 \\
\hline $2-24$ & SSDQEMAIFGEAAPYLRKSEKER & $\begin{array}{l}\text { Prot Terminal Acetyl_N-term; } \\
\text { Ox(M)_6 }\end{array}$ & 900.78 & 900.77 & 3 & 2699.33 & 99 & & $\mathrm{X}$ & $\mathrm{X}$ & \\
\hline $2-18$ & SSDQEMAIFGEAAPYLR & Prot Terminal Acetyl_N-term & 963.96 & 963.95 & 2 & 1925.91 & 99 & $\mathrm{X}$ & $\mathrm{X}$ & $\mathrm{X}$ & \\
\hline $19-37$ & KSEKERIEAQNKPFDAKTS & Methyl(K)_17 & 740.74 & 740.73 & 3 & 2219.20 & 99 & $\mathrm{X}$ & & $\mathrm{X}$ & \\
\hline $19-37$ & KSEKERIEAQNKPEDAKTS & Deamidated(Q)_10; Methyl(K)_17 & 741.07 & 741.05 & 3 & 2220.18 & 99 & $\mathrm{X}$ & & $\mathrm{X}$ & \\
\hline $19-37$ & KSEKERIEAQNKPFDAKTS & Methyl(T)_18 & 740.72 & 740.73 & 3 & 2219.15 & 99 & $\mathrm{X}$ & & $\mathrm{X}$ & \\
\hline $19-35$ & KSEKERIEAQNKPFDAK & - & 673.38 & 673.36 & 3 & 2017.10 & 99 & $\mathrm{X}$ & & $\mathrm{X}$ & \\
\hline $19-35$ & KSEKERIEAQNKPFDAK & Methyl(D)_15 & 678.05 & 678.03 & 3 & 2031.13 & 99 & $\mathrm{X}$ & & $\mathrm{X}$ & \\
\hline $19-35$ & KSEKERIEAQNKPFDAK & Deamidated(N) 11 & 673.70 & 673.69 & 3 & 2018.07 & 99 & $\mathrm{X}$ & & & \\
\hline $40-57$ & VAEPKESFVKGTVQSREG & - & 650.02 & 650.01 & 3 & 1947.04 & 99 & $\mathrm{X}$ & $\mathrm{X}$ & $\mathrm{X}$ & \\
\hline $40-57$ & VAEPKESFVKGTVQSREG & Deamidated(Q)_14 & 650.35 & 650.34 & 3 & 1948.02 & 99 & & $\mathrm{X}$ & $\mathrm{X}$ & \\
\hline $40-57$ & VAEPKESFVKGTVQSREG & Methyl(E)_17 & 654.69 & 654.68 & 3 & 1961.05 & 99 & & & $\mathrm{X}$ & \\
\hline $40-57$ & VAEPKESFVKGTVQSREG & Methyl(E)_6 & 654.69 & 654.68 & 3 & 1961.03 & 99 & & $\mathrm{X}$ & $\mathrm{X}$ & \\
\hline $40-57$ & VAEPKESFVKGTVQSREG & Methyl(E)_3 & 654.69 & 654.68 & 3 & 1961.03 & 99 & & $\mathrm{X}$ & $\mathrm{X}$ & \\
\hline $40-57$ & VAEPKESFVKGTVQSREG & Methyl(S)_7 & 654.69 & 654.68 & 3 & 1961.04 & 99 & & $\mathrm{X}$ & $\mathrm{X}$ & \\
\hline $40-57$ & VAEPKESFVKGTVQSREG & Ox(P)_4; Methyl(E)_17 & 660.03 & 660.01 & 3 & 1977.08 & 99 & & & $\mathrm{X}$ & \\
\hline $40-57$ & VAEPKESFVKGTVQSREG & Formyl(K)_5 & 659.36 & 659.34 & 3 & 1975.07 & 99 & & $\mathrm{X}$ & $\mathrm{X}$ & \\
\hline $40-57$ & VAEPKESFVKGTVQSREG & Dimethyl(R)_16 & 659.70 & 659.35 & 3 & 1976.09 & 96 & & & $\mathrm{X}$ & \\
\hline $40-56$ & VAEPKESFVKGTVQSRE & - & 631.02 & 631.00 & 3 & 1890.04 & 99 & & & $\mathrm{X}$ & \\
\hline $40-56$ & VAEPKESFVKGTVQSRE & Methyl(E)_3 & 635.68 & 635.67 & 3 & 1904.03 & 99 & & $\mathrm{X}$ & $\mathrm{X}$ & \\
\hline $40-53$ & VAEPKESFVKGTVQ & Deamidated(Q)_14 & 760.43 & 760.40 & 2 & 1518.84 & 99 & $\mathrm{X}$ & & $\mathrm{X}$ & \\
\hline $40-50$ & VAEPKESFVKG & - & 595.84 & 595.82 & 2 & 1189.66 & 99 & $\mathrm{X}$ & $\mathrm{X}$ & $\mathrm{X}$ & \\
\hline $41-57$ & AEPKESFVKGTIQSREG & - & 621.66 & 621.66 & 3 & 1861.97 & 99 & & $X$ & & \\
\hline
\end{tabular}




\begin{tabular}{|c|c|c|c|c|c|c|c|c|c|c|}
\hline $41-57$ & AEPKESFVKGTIQSREG & - & 621.66 & 621.66 & 3 & 1861.97 & 98 & & $\mathrm{X}$ & \\
\hline $58-70$ & GKVTVKTEAGATL & - & 637.89 & 637.87 & 2 & 1273.76 & 99 & $\mathrm{X}$ & $\mathrm{X}$ & $\mathrm{X}$ \\
\hline $58-68$ & GKVTVKTEAGA & - & 530.81 & 530.80 & 2 & 1059.60 & 98 & $\mathrm{X}$ & $\mathrm{X}$ & $\mathrm{X}$ \\
\hline $71-90$ & TVKEDQVFPMNPPKFDKIED & - & 793.07 & 793.06 & 3 & 2376.19 & 99 & & $\mathrm{X}$ & $\mathrm{X}$ \\
\hline $71-90$ & TVKEDQVFPMNPPKFDKIED & Ox(M)_10; Deamidated(N)_11 & 798.75 & 798.72 & 3 & 2393.23 & 99 & & $\mathrm{X}$ & $\mathrm{X}$ \\
\hline $71-90$ & TVKEDQVFPMNPPKFDKIED & Deamidated(Q)_6; Ox(M)_10 & 798.74 & 798.72 & 3 & 2393.20 & 99 & & $\mathrm{X}$ & $\mathrm{X}$ \\
\hline $71-90$ & TVKEDQVFPMNPPKFDKIED & $\begin{array}{l}\text { Deamidated(N)_11 } \\
\text { Deamidated(Q) 6; }\end{array}$ & 793.41 & 793.39 & 3 & 2377.20 & 99 & & $\mathrm{X}$ & $\mathrm{X}$ \\
\hline $71-90$ & TVKEDQVFPMNPPKFDKIED & Deamidated(N)_11 & 793.74 & 793.72 & 3 & 2378.21 & 99 & & $\mathrm{X}$ & $\mathrm{X}$ \\
\hline $71-90$ & TVKEDQVFPMNPPKFDKIED & Methyl(D)_20 & 797.75 & 797.73 & 3 & 2390.22 & 99 & & $\mathrm{X}$ & $\mathrm{X}$ \\
\hline $71-86$ & TVKEDQVFPMNPPKFD & $\mathrm{Ox}(\mathrm{M}) \_10$ & 954.48 & 954.46 & 2 & 1906.95 & 99 & & $\mathrm{X}$ & $\mathrm{X}$ \\
\hline $71-86$ & TVKEDQVFPMNPPKFD & - & 946.48 & 946.47 & 2 & 1890.95 & 99 & & $\mathrm{X}$ & $\mathrm{X}$ \\
\hline $71-86$ & TVKEDQVFPMNPPKFD & - & 631.32 & 631.31 & 3 & 1890.95 & 99 & & $\mathrm{X}$ & $\mathrm{X}$ \\
\hline $71-86$ & TVKEDQVFPMNPPKFD & Ox(M)_10; Deamidated(N)_11 & 636.99 & 636.97 & 3 & 1907.95 & 97 & & $\mathrm{X}$ & $\mathrm{X}$ \\
\hline $71-84$ & TVKEDQVFPMNPPK & $\mathrm{Ox}(\mathrm{M}) \_10$ & 823.43 & 823.42 & 2 & 1644.84 & 99 & $X$ & $\mathrm{X}$ & $\mathrm{X}$ \\
\hline $71-83$ & TVKEDQVFPMNPP & - & 751.38 & 751.37 & 2 & 1500.75 & 99 & $X$ & $\mathrm{X}$ & $\mathrm{X}$ \\
\hline $72-90$ & VKEDQVFPMNPPKFDKIED & - & 759.39 & 759.38 & 3 & 2275.15 & 99 & & $\mathrm{X}$ & $\mathrm{X}$ \\
\hline $72-90$ & VKEDQVFPMNPPKFDKIED & $\mathrm{Ox}(\mathrm{P}) \_8$ & 764.70 & 764.71 & 3 & 2291.09 & 99 & & $\mathrm{X}$ & $\mathrm{X}$ \\
\hline $72-90$ & VKEDQVFPMNPPKFDKIED & $\mathrm{Ox}(\mathrm{M}) \_9$ & 764.73 & 764.71 & 3 & 2291.16 & 99 & & $\mathrm{X}$ & $\mathrm{X}$ \\
\hline $72-90$ & VKEDQVFPMNPPKFDKIED & Ox(M)_9; Deamidated(N)_10 & 765.07 & 765.04 & 3 & 2292.18 & 99 & & $\mathrm{X}$ & $\mathrm{X}$ \\
\hline $72-90$ & VKEDQVFPMNPPKFDKIED & Deamidated(Q)_5; Ox(M)_9 & 765.05 & 765.04 & 3 & 2292.14 & 99 & & $\mathrm{X}$ & $\mathrm{X}$ \\
\hline $72-90$ & VKEDQVFPMNPPKFDKIED & Deamidated(N)_10 & 759.73 & 759.71 & 3 & 2276.16 & 99 & & $\mathrm{X}$ & $\mathrm{X}$ \\
\hline $72-90$ & VKEDQVFPMNPPKFDKIED & Deamidated(Q)_5 & 759.72 & 759.71 & 3 & 2276.13 & 99 & & $\mathrm{X}$ & $\mathrm{X}$ \\
\hline $72-90$ & VKEDQVFPMNPPKFDKIED & Deamidated(N)_10; Methyl(D)_15 & 764.40 & 764.38 & 3 & 2290.18 & 97 & & $\mathrm{X}$ & $\mathrm{X}$ \\
\hline $72-89$ & VKEDQVFPMNPPKFDKIE & - & 721.04 & 721.04 & 3 & 2160.11 & 99 & & $\mathrm{X}$ & $\mathrm{X}$ \\
\hline $72-86$ & VKEDQVFPMNPPKFD & - & 895.95 & 895.94 & 2 & 1789.89 & 99 & & $\mathrm{X}$ & $\mathrm{X}$ \\
\hline $72-86$ & VKEDQVFPMNPPKFD & Deamidated(Q)_5 & 896.45 & 896.43 & 2 & 1790.89 & 99 & & X & $X$ \\
\hline
\end{tabular}




\begin{tabular}{|c|c|c|c|c|c|c|c|c|c|c|c|}
\hline $72-86$ & VKEDQVFPMNPPKFD & Ox(M)_9; Deamidated(N)_10 & 904.46 & 904.43 & 2 & 1806.90 & 97 & & $\mathrm{X}$ & $\mathrm{X}$ & \\
\hline $72-86$ & VKEDQVFPMNPPKFD & $\mathrm{Ox}(\mathrm{M}) \_9$ & 903.96 & 903.94 & 2 & 1805.91 & 99 & & $\mathrm{X}$ & & $\mathrm{X}$ \\
\hline $74-90$ & EDQVFPMNPPKFDKIED & $\mathrm{Ox}(\mathrm{M}) \_7$ & 689.00 & 688.99 & 3 & 2063.99 & 99 & & $\mathrm{X}$ & $\mathrm{X}$ & \\
\hline $82-90$ & PPKEDKIED & - & 544.79 & 544.78 & 2 & 1087.57 & 98 & & $\mathrm{X}$ & $\mathrm{X}$ & \\
\hline $145-155$ & GKKRQEAPPHI & - & 630.88 & 630.86 & 2 & 1259.74 & 99 & $\mathrm{X}$ & $\mathrm{X}$ & $\mathrm{X}$ & \\
\hline $168-182$ & TDRENQSILITGESG & - & 810.40 & 810.40 & 2 & 1618.79 & 99 & $\mathrm{X}$ & $\mathrm{X}$ & $\mathrm{X}$ & $\mathrm{X}$ \\
\hline 177-194 & ITGESGAGKTVNTKRVIQ & - & 620.36 & 620.35 & 3 & 1858.06 & 99 & $\mathrm{X}$ & $\mathrm{X}$ & $\mathrm{X}$ & $\mathrm{X}$ \\
\hline $197-216$ & ATIAVTGEKKKEEPTPGKMQ & Ox(M)_19; Deamidated(Q)_20 & 720.74 & 720.71 & 3 & 2159.20 & 99 & & & $\mathrm{X}$ & \\
\hline $199-221$ & IAVTGEKKKEEPTPGKMQGTLED & $\mathrm{Ox}(\mathrm{M}) \_17$ & 834.79 & 834.76 & 3 & 2501.35 & 99 & & & $\mathrm{X}$ & \\
\hline $199-216$ & IAVTGEKKKEEPTPGKMQ & $\mathrm{Ox}(\mathrm{M}) \_17$ & 663.03 & 663.02 & 3 & 1986.06 & 99 & & & $\mathrm{X}$ & \\
\hline $199-215$ & IAVTGEKKKEEPTPGKM & $\mathrm{Ox}(\mathrm{M}) \_17$ & 620.35 & 620.34 & 3 & 1858.02 & 99 & & & $\mathrm{X}$ & \\
\hline $199-212$ & IAVTGEKKKEEPTP & - & 763.93 & 763.92 & 2 & 1525.85 & 99 & & & $\mathrm{X}$ & \\
\hline $199-212$ & IAVTGEKKKEEPTP & - & 509.62 & 509.62 & 3 & 1525.84 & 99 & & & $\mathrm{X}$ & \\
\hline $405-422$ & PRVKVGNEFVTKGQTVQQ & - & 672.38 & 672.37 & 3 & 2014.11 & 99 & & & $\mathrm{X}$ & \\
\hline $405-417$ & PRVKVGNEFVTKG & - & 715.91 & 715.91 & 2 & 1429.81 & 99 & & & $\mathrm{X}$ & \\
\hline $405-416$ & PRVKVGNEFVTK & - & 687.40 & 687.40 & 2 & 1372.78 & 99 & & & $\mathrm{X}$ & \\
\hline $624-650$ & FTGAAGADAEAGGGKKGGKKKGSSFQT & - & 838.45 & 838.43 & 3 & 2512.33 & 99 & $\mathrm{X}$ & & & \\
\hline $624-648$ & FSGAQTGEAEAGGTKKGGKKKGSSF & - & 805.77 & 805.75 & 3 & 2414.28 & 99 & & $\mathrm{X}$ & & \\
\hline $628-648$ & YAGADTPVEKGKGKAKKGSSF & - & 709.40 & 709.38 & 3 & 2125.18 & 99 & & & & $\mathrm{X}$ \\
\hline $638-648$ & TKKGGKKKGSSF & - & 626.89 & 626.87 & 2 & 1251.76 & 99 & & & $\mathrm{X}$ & \\
\hline $638-648$ & TKKGGKKKGSSF & - & 626.89 & 626.87 & 2 & 1251.76 & 99 & & $\mathrm{X}$ & & \\
\hline $678-690$ & IPNETKTPGAMEH & $\mathrm{Ox}(\mathrm{M}) \_11$ & 720.86 & 720.84 & 2 & 1439.70 & 96 & & $\mathrm{X}$ & $\mathrm{X}$ & \\
\hline $730-744$ & NASAIPEGQFIDSKK & Deamidated(N)_1 & 803.42 & 803.41 & 2 & 1604.82 & 99 & $\mathrm{X}$ & & $\mathrm{X}$ & \\
\hline $733-748$ & AIPEGQFIDSKKASEK & - & 874.47 & 874.46 & 2 & 1746.93 & 99 & & & $\mathrm{X}$ & \\
\hline $733-749$ & AIPEGQFIDSKKASEKL & - & 621.01 & 621.01 & 3 & 1860.01 & 99 & $\mathrm{X}$ & & $\mathrm{X}$ & \\
\hline $734-744$ & IPEGQFIDSKK & - & 631.35 & 631.34 & 2 & 1260.68 & 99 & & & $\mathrm{X}$ & \\
\hline
\end{tabular}




\begin{tabular}{|c|c|c|c|c|c|c|c|c|c|c|c|}
\hline $739-749$ & FIDSKKASEKL & - & 633.37 & 633.36 & 2 & 1264.72 & 99 & & & $\mathrm{X}$ & \\
\hline $751-766$ & GSIDIDHTQYKFGHTK & Methyl(H)_7 & 620.98 & 620.98 & 3 & 1859.93 & 99 & $\mathrm{X}$ & & $\mathrm{X}$ & \\
\hline $752-766$ & SIDIDHTQYKFGHTK & Methyl(H)_6 & 601.98 & 601.97 & 3 & 1802.90 & 99 & $\mathrm{X}$ & $\mathrm{X}$ & $\mathrm{X}$ & \\
\hline $753-766$ & IDIDHTQYKFGHTK & Methyl(H)_5 & 572.97 & 572.96 & 3 & 1715.88 & 99 & $\mathrm{X}$ & $\mathrm{X}$ & $\mathrm{X}$ & \\
\hline $754-766$ & DIDHTQYKFGHTK & Methyl(H)_4 & 535.27 & 535.27 & 3 & 1602.79 & 99 & & $\mathrm{X}$ & $\mathrm{X}$ & \\
\hline $755-766$ & IDHTQYKFGHTK & Methyl(H)_3 & 496.93 & 496.92 & 3 & 1487.77 & 99 & $\mathrm{X}$ & $X$ & $\mathrm{X}$ & \\
\hline $751-766$ & GSLDIDHNQYKFGHTK & Deamidated(N) 8 & 620.99 & 620.97 & 3 & 1859.94 & 99 & & & & $\mathrm{X}$ \\
\hline $837-853$ & FKIKPLLKSAETEKEM & $\mathrm{Ox}(\mathrm{M}) \_16$ & 636.69 & 636.69 & 3 & 1907.06 & 99 & $\mathrm{X}$ & & $\mathrm{X}$ & \\
\hline $838-853$ & KIKPLLKSAETEKEM & $\mathrm{Ox}(\mathrm{M}) \_15$ & 587.67 & 587.67 & 3 & 1759.99 & 99 & $\mathrm{X}$ & & $\mathrm{X}$ & \\
\hline $839-853$ & IKPLLKSAETEKEM & $\mathrm{Ox}(\mathrm{M}) \_14$ & 544.98 & 544.97 & 3 & 1631.90 & 96 & $\mathrm{X}$ & & $\mathrm{X}$ & \\
\hline 1907-1919 & LDEAEERADIAESQVNK & - & 639.66 & 639.64 & 3 & 1915.97 & 99 & & & & $\mathrm{X}$ \\
\hline
\end{tabular}

a- Position of the peptides inside the corresponding MYH sequence. ${ }^{\mathrm{b}}$ - Modifications observed in some amino acids of the peptides. The number indicates the position of the modification in the peptide sequence. ${ }^{\mathrm{c}}$ - Observed peptide mass in the detector after ionisation using nESI. ${ }^{\mathrm{d}}$ - Expected mass calculated from the observed mass according to the charge state of the ion. ${ }^{\mathrm{e}}$ -

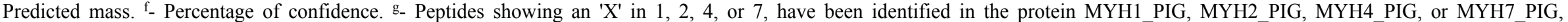
respectively. 
